\title{
Bone Marrow Oxalosis: Crystal Flowers in the Bone Marrow Garden
}

\author{
Kemik Iliği Oksalozisi: Kemik Iliği Bahçesinde Kristal Çiçekler
}

(D) Nabhajit Mallik, (D) Man Updesh Singh Sachdeva

Postgraduate Institute of Medical Education and Research, Department of Hematology, Chandigarh, India

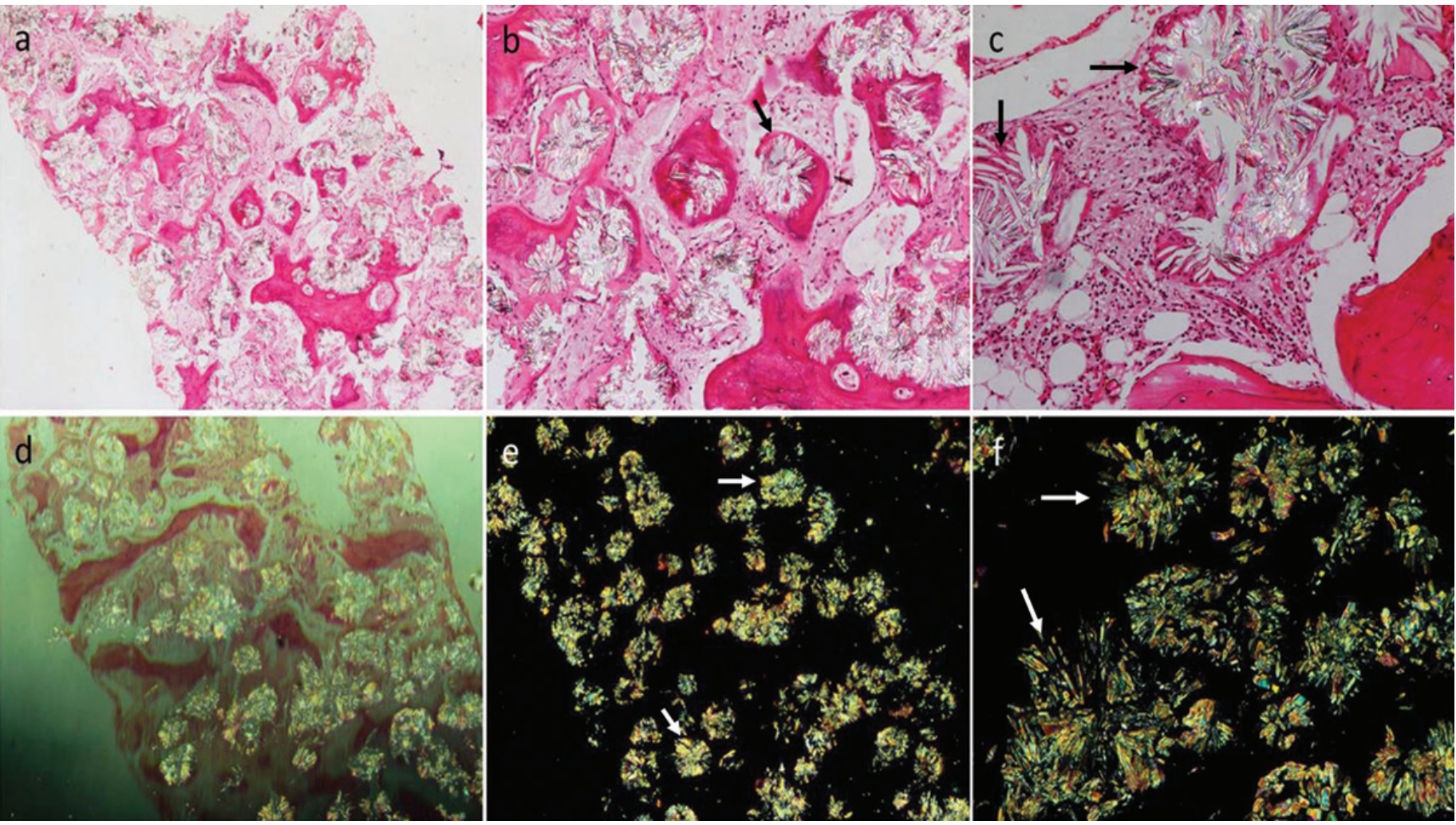

Figure 1. Bilateral bone biopsy core showed replacement of bone marrow with extensive interstitial and paratrabecular deposition of crystals accompanied by fibrosis $\left(a, 100^{*} ; b\right.$ and $\left.c_{1} 400^{x}\right)$. Crystals were translucent and rod-shaped, arranged in a rosette-like pattern, and birefringent under polarized light, consistent with calcium oxalate crystals ( $d$ and e, 100 $;$, 400).

A 20-year-old male with a known case of chronic kidney disease had been diagnosed with nephrolithiasis at the age of 8 months. Since then, he had recurrent renal stones leading to end-stage renal disease and was scheduled for a renal transplant. A computed tomography scan showed bilateral small kidneys with right-sided nephrolithiasis. Complete blood counts revealed hemoglobin level of $70 \mathrm{~g} / \mathrm{L}$, white blood cell count of $8.1 \times 10^{9} / \mathrm{L}$, and platelet count of $395 \times 10^{9} / \mathrm{L}$. Bilateral bone marrow biopsies were performed to investigate the cause of persistent anemia, and one of the cores showed replacement of bone marrow with extensive interstitial and paratrabecular deposition of crystals accompanied by fibrosis (Figures $1 \mathrm{a}, 100^{\mathrm{x}}$, and $1 \mathrm{~b}-1 \mathrm{c}, 400^{\mathrm{x}}$ ). The crystals appeared translucent and rod-shaped, and they were arranged in a rosette-like pattern. They were birefringent under

(1) orcid.org/0000-0002-4406-8299 
polarized light, consistent with calcium oxalate crystals (Figures $1 d-1 e, 100^{x}$, and $\left.1 f, 400^{x}\right)$.

Systemic oxalosis results in the deposition of calcium oxalate crystals mainly in the myocardium, cardiac conduction system, kidneys, bones, or bone marrow [1]. This case demonstrates that although bone marrow examination may not be a routine modality for the diagnosis of hyperoxaluria, it should definitely be considered in young patients with renal failure and childhood recurrent nephrolithiasis who present with cytopenia/refractory anemia.

Keywords: Oxalosis, Crystals, Bone marrow

Anahtar Sözcükler: Oksalozis, Kristaller, Kemik iliği

\section{Authorship Contributions}

Concept: N.M., M.U.S.S.; Design: N.M., M.U.S.S.; Data Collection or Processing: N.M., M.U.S.S.; Analysis or Interpretation: N.M., M.U.S.S.; Literature Search: N.M., M.U.S.S.; Writing: N.M., M.U.S.S.

Conflict of Interest: No conflict of interest was declared by the authors.

Financial Disclosure: The authors declared that this study received no financial support.

\section{Reference}

1. Sriram K, Kekre NS, Gopalakrishnan G. Primary hyperoxaluria and systemic oxalosis. Indian J Urol 2007;23:79-80. 